\title{
As cidades falam?
}

\author{
Texto original:
}

\section{Saskia Sassen}

Saskia Sassen (5 de janeiro de 1947) é uma socióloga holandesa-americana conhecida por suas análises da globalização e da migração humana internacional e seus impactos no contexto urbano.

Ela é The Robert S. Lynd Professor of Sociology na Universidade de Columbia e membro do Comitê de Pensamento Global da mesma universidade. Publicou 12 livros, juntos traduzidos para mais de 20 idiomas, como The Global City (Princeton University Press, [1991] 2. ed., 2001), no qual desenvolveu o termo "cidade global". Ela recebeu diversos prêmios e menções, incluindo 12 doutorados honoris causa, e foi selecionada como uma das principais pensadoras globais em diversas listas. Mais recentemente, recebeu o Prémio Príncipe de Astúrias 2013 nas Ciências Sociais e foi nomeada Membro Estrangeiro da Real Academia das Ciências da Holanda.

Contato: http://www.saskiasassen.com/

Tradução:

\section{Henrique C. Delarue}

Arquiteto pelo Departamento de Arquitetura e Urbanismo da PUC-Rio.

Contato: hcdelarue@gmail.com

Revisão técnica:

\section{Silvio Dias}

Professor do Departamento de Arquitetura e Urbanismo da PUC-Rio.

Contato: silviodias@puc-rio.br

Este artigo foi publicado originalmente em Inglês como: SASSEN, Saskia. Does the city have speech?. Public Culture. Durham, v. 25, n. 2, p. 209-221, jul. 2013.

A Revista Prumo agradece a generosidade da autora em ceder a autorização para tradução e publicação deste artigo. 
A voz ${ }^{1}$ é um elemento fundamental nas teorias sobre democracia e política. Como conceito, teve seu significado tanto expandido quanto contraído. Mas, pelo que posso dizer e pelo que outros me disseram, ainda não se expandiu o suficiente para incluir o conceito de que a cidade pudesse ter uma voz. Argumentar, como faço neste ensaio, que as cidades têm uma voz - independentemente de ser muito diferente daquela dos cidadãos e das empresas - é, em muitos aspectos, uma questão transversal tanto para o direito quanto para o planejamento urbano. Tal conceito não está presente em nenhum desses campos de estudo, principalmente porque não confino a noção de voz à de governo urbano, tampouco construo o conteúdo da voz da cidade nos termos indicados pela lei. Portanto, esta pesquisa exige ampliar o campo analítico para examinar o conceito de cada um: a voz e a cidade.

As cidades são sistemas complexos, mas são sistemas incompletos. Nessa incompletude, está a possibilidade de fazer - fazer o urbano, ${ }^{2}$ o político, o cívico. A cidade não é a única com essas características, mas elas são uma parte necessária do DNA do urbano - ser cidade (cityness). Cada cidade é diferente, assim como cada disciplina que a estuda. No entanto, se é um estudo do urbano, deve lidar com estes traços distintivos: incompletude, complexidade e factibilidade. Esses recursos assumem formatos urbanos que podem variar enormemente no tempo e no espaço.

Dada essa diversidade, a pesquisa urbana não precisa reconhecer versões abstratas e destiladas desses três conceitos centrais - complexidade, incompletude e produção. Na maior parte dos casos, pesquisadores e intérpretes urbanos usam ou invocam os conceitos de suas disciplinas ou de sua imaginação, bem como as características concretas das cidades que observam. Mas essas três características abstratas estão presentes se for realmente o urbano, e não simplesmente um terreno densamente construído de um tipo específico - filas infinitas de casas, escritórios ou fábricas. Assim, uma vasta faixa de residências suburbanas não é uma cidade, mas um terreno construído, da mesma forma que parques empresariais. Se quisermos que o conceito de cidade funcione analiticamente, devemos discriminá-lo conceitualmente.

Aqui, uso esses atributos das cidades para me engajar em uma pesquisa experimental. Argumentarei que existem eventos e condições que nos dizem algo sobre a capacidade das cidades de responder sistematicamente - nos contestar. Deixe-me oferecer um esboço inicial do que quero dizer com um exemplo simples: um carro, construído para rodar em alta velocidade, sai da rodovia e entra na cidade. Ele chega a uma área com tráfego, composta não só de carros, mas de pessoas que transbordam por toda parte. De repente, o carro fica incapacitado. Construído para velocidade, sua mobilidade é tomada. A cidade falou.

Uma abordagem primária é pensar essa voz como uma capacidade urbana. O termo capacidade $^{3}$ já está bem estabelecido. Mas qualificá-lo como capacidade urbana é incomum. Eu o apresento assim para capturar a mistura indescritível de espaço, pessoas e atividades particulares, especialmente comércio e atividades cívicas. Esse termo captura os aspectos sociais e físicos da cidade. Entendida dessa forma, a noção de capacidade urbana funciona como uma fronteira analítica $^{4}$ - nem apenas o espaço urbano e nem apenas as pessoas (ver SASSEN, 2008, cap.8). É sua combinação em condições específicas, em cenários consistentes, confrontando potenciais e certas agressões que podem dar voz. Essas capacidades urbanas tornam-se visíveis em uma variedade de situações e formas. Ao se tornarem visíveis, tornam-se uma forma de fala.

É impossível fazer jus a todos os aspectos desse processo em um ensaio tão curto, então vou me limitar aos blocos básicos de construção do argumento. Primeiro, a cidade como um sistema complexo e incompleto que permite produções e que deu às cidades sua longa vida; a combinação desses dois aspectos permitiu que sobrevivessem a sistemas mais poderosos, mas também mais formais e fechados - Estados Nacionais, reinos e empresas financeiras. Segundo, a mistura de várias capacidades urbanas que podem ser concebidas como atos de fala e que, por sua vez, sinalizam a noção mais ampla de que as cidades têm uma voz, mesmo que seja informal e geralmente não seja reconhecido como tal.

A racionalidade substancial que subjaz a esta pesquisa sobre a cidade e a voz baseia-se em duas questões. Em primeiro lugar, o fato de a cidade ainda ser um espaço fundamental para as práticas materiais de liberdade, incluindo suas anarquias e contradições, e um espaço onde quem não tem poder (the powerless) pode exercer sua fala, presença, política. A outra é que esses aspectos da cidade são ameaçados por uma variedade de processos agudos que desurbanizam as cidades, por mais densas e urbanas que pareçam; essas ameaças incluem formas extremas de desigualdade e privatização, novos tipos de violência urbana, guerras assimétricas e sistemas massivos de vigilância. No entanto, para ver isso é preci-

Revista online do Departamento de Arquitetura e Urbanismo da 
so também dedicar um tempo para ouvir e, talvez, entender a voz da cidade. Além disso, é bem possível que tenhamos esquecido como ouvi-la, para não dizer como entendê-la. A seguir exploro alguns atos de fala da cidade. ${ }^{5}$

\section{Táticas analíticas}

Ao fazer esse tipo de meditação experimental, vejo a necessidade de me engajar livremente no que me parece uma tática analítica. O método limita muito. Uma dessas táticas é operar à sombra de explicações poderosas, que devem ser levadas a sério, mas que são perigosas. Meu primeiro passo é perguntar o que exatamente esse tipo de explicação obscurece, uma vez que lança uma luz muito poderosa sobre alguns aspectos do assunto. Ao explorar a noção de que as cidades falam, não posso me alongar nas explicações poderosas que nos dizem o que é a cidade. A fala da cidade ocorre em uma zona intermediária: não é a cidade simplesmente como uma ordem social ou material. É uma capacidade urbana elusiva - não é totalmente material, nem totalmente visível.

Uma segunda tática analítica, parcialmente derivada da primeira, é a necessidade de desestabilizar ativamente significados estabelecidos. Ao fazê-lo, permitimo-nos ver ou compreender o que não está contido nas narrativas centrais que explicam uma época ou que organizam um campo acadêmico - e precisamos fazê-lo especialmente em tempos de rápida transformação. Portanto, a própria noção de que a cidade tem voz implica desestabilizar a noção de que a cidade é uma condição evidente marcada pela densidade, pela materialidade, pelas multidões e suas múltiplas interações. A esmagadora facticidade da cidade precisa ser desestabilizada. Estou interessada em recuperar a possibilidade de que uma exposição interativa de pessoas, empresas, infraestruturas, edifícios, projetos, imaginários e muito mais, em um terreno confinado, produza algo semelhante à voz: resistência, potencialidades aprimoradas, enfim, que a cidade nos conteste.

\section{Complexidade e incompletude: a possibilidade de produções}

As cidades são um dos principais locais onde novas normas e identidades são feitas. Elas estiveram nesses locais em várias épocas, em vários lugares e em condições muito diferentes. Assim, mesmo que as cidades tenham sido por muito tempo o lar do racismo, do ódio religioso ou da expulsão dos pobres, elas demonstraram ao longo da história uma capacida- de de realizar uma triagem do conflito por meio do comércio e da atividade cívica. Isso contrasta com a história do Estado Nacional moderno, que tendeu a militarizar o conflito. As condições que permitem as cidades a construir normas e identidades e transformar conflitos em civismo fortalecido variam no tempo e no espaço.

A mudança de época, como em nossa transição para o global, tende a ser uma fonte de novos tipos de capacidades urbanas. Hoje, dada a globalização e a digitalização e todos os elementos específicos que implicam - muitas dessas condições mudaram novamente. A globalização e a digitalização produzem deslocamentos e desestabilizam as ordens institucionais existentes, que vão além das cidades. Mas a coordenação desproporcional e agudeza dessas novas dinâmicas nas cidades, especialmente nas cidades globais, força a necessidade de se criar novos tipos de respostas e inovar, especialmente por parte tanto de quem tem mais poder quanto dos menos favorecidos, ainda que por razões bem diferentes. Algumas dessas normas e identidades justificam o poder extremo e a desigualdade. Algumas refletem a inovação sob pressão - como visto em muito do que acontece em bairros de imigrantes ou favelas das megacidades. Embora as transformações estratégicas tenham formas bem delineadas e se concentrem em cidades globais, algumas também acontecem - além de se espalharem - em cidades que não são centros de poder ou de extrema desigualdade.

Nem sempre as cidades são os locais-chave para a construção de novas normas e identidades ou inovações institucionais. Por exemplo, na Europa e em grande parte do hemisfério ocidental, dos anos 1930 aos anos 1970, a fábrica e o governo eram locais estratégicos para a inovação por meio do contrato social e da capacitação - baseada na produção e consumo em massa - de uma próspera classe média trabalhadora. Minha própria leitura da cidade fordista corresponde em muitos aspectos à noção de Max Weber de que a cidade moderna não é um espaço para inovação, diferentemente das cidades medievais na Europa. A escala estratégica sob o fordismo é nacional; nela, as cidades perdem seu significado. Mas me afasto de Weber ao compreender que, historicamente, a grande fábrica fordista e as minas foram locais de inovação: a configuração de uma classe trabalhadora moderna e o projeto sindicalista. Em suma, nem sempre é a cidade que é o lugar para se produzir normas e identidades.

Em nossa era global, as cidades reaparecem como locais estratégicos para mudanças culturais e institucionais. As

Revista online do Departamento de Arquitetura e Urbanismo da 
condições que hoje tornam algumas cidades locais estratégicos são basicamente duas - e ambas envolvem grandes transformações que desestabilizam os sistemas mais antigos ao organizarem o território e a política. Uma delas é a alteração de escala dos territórios estratégicos que articulam o novo sistema político-econômico e, portanto, ao menos alguns aspectos do poder. A outra é o enfraquecimento do nacional como contentor de processos sociais devido à variedade de dinâmicas que a globalização e a digitalização envolvem. As consequências para as cidades dessas duas condições são muitas, mas o que importa aqui é que surgem como locais estratégicos para grandes processos econômicos e para novos tipos de atores políticos, incluindo processos e agentes fora da urbanidade.

Uma distinção importante para minha avaliação está entre espaços ritualizados, que reconhecemos como tais, e espaços que ou não são ritualizados, ou que falhamos em reconhecer como tais. Muito do que experienciamos como urbanidade em nossa tradição européia ocidental é um conjunto de práticas e condições que passaram por um refinamento e uma ritualização ao longo do tempo e através do espaço. Sendo assim, em nossa tradição europeia parcialmente imaginada, a passeggiata não é qualquer passeio, e a piazza não é qualquer praça. ${ }^{7}$ Ambas têm genealogias incorporadas de significado e ritual; ambas contribuem com a constituição do domínio público por meio da ritualização.

Através do tempo, assim como do espaço, a história nos oferece vislumbres de um tipo bem diferente de espaço, um menos ritualizado e com poucos, ou nenhum, códigos inscritos. É um espaço para a ação por quem não tem acesso a instrumentos estabelecidos. Tenho trabalhado na recuperação conceitual desse tipo de espaço e o tenho chamado de "rua global" (SASSEN, 2011). É um espaço com poucas, ou nenhuma, práticas ritualizadas ou códigos que a sociedade em geral possa reconhecer. Ele é bruto e facilmente visto como "incivilizado".

A cidade - e principalmente a rua - é um espaço onde populações que não têm poder podem fazer história de formas que seriam impossíveis no meio rural. Isso não significa que seja o único, mas certamente é um espaço crítico. Ao se tornarem visíveis, presentes umas às outras, elas podem alterar o caráter da sua falta de poder (powerlessness). Isso torna possível distinguir entre diferentes tipos dessa falta de poder (SASSEN, 2008, cap. 6 e 8). Esse não é simplesmente um estado absoluto que pode ser achatado como ausência de poder.
Sob certas condições, a falta de poder pode ser complexa, o que quer dizer que existe a possibilidade de se fazer o político, o cívico e uma história. Isso nos confronta com o fato de que existe uma diferença entre falta de poder e invisibilidade/impotência. Muitos movimentos de protesto que vimos no Oriente Médio e Norte da África, na Europa, nos Estados Unidos e em outros lugares ilustram essa questão: aqueles que protestam podem não ter conquistado o poder, eles ainda não têm poder, mas estão fazendo história e política.

Isso me leva a uma segunda distinção, que contém uma crítica à noção comum de que se algo bom acontece àqueles que não têm poder, isso sinaliza seu empoderamento. Reconhecer que a falta de poder pode se tornar complexa abre um espaço conceitual para a proposta de que quem não tem poder pode fazer história, mesmo que não se tornem empoderados e, portanto, seu trabalho tem consequências mesmo que não sejam rapidamente visíveis e que possam, de fato, levar gerações para se materializar. Em outros momentos (SASSEN, 2008, cap. 2, 3 e 6), interpretei várias historiografias como indicadores de que o período de tempo das histórias construídas por aqueles que não têm poder tende a ser muito mais longo do que o das histórias construídas por aqueles que o detêm.

\section{Capacidades urbanas: precedem a fala e a tornam legível}

Se a cidade tem uma voz, como ela pode se parecer ou soar? Qual língua fala? Como se torna legível para nós, que falamos outra língua e cuja voz é, no mínimo, uma cacofonia?

Um primeiro pequeno passo é propor que a voz da cidade seja uma capacidade de alterar, moldar, provocar, convidar, tudo em busca de uma lógica que almeja acentuar ou proteger a complexidade e incompletude da cidade. Deixe-me elaborar isso de um modo um tanto exagerado, por uma questão de clareza, e argumentar que focar apenas na facticidade da cidade não é suficiente para entender a questão de saber se ela tem uma voz.

A questão da voz da cidade não pode ser reduzida a essa facticidade, mesmo que requeira o reconhecimento e um despertar analítico dessa facticidade. Em outras palavras, temos achatado a facticidade da cidade, quando na verdade deveríamos tornar visíveis suas diferenciações para que possam funcionar analiticamente. Essa forma de aplanamento não nos ajuda a ver como a facticidade interage com as ações das pessoas, ou que aí há uma construção, uma construção

Revista online do Departamento de Arquitetura e Urbanismo da 


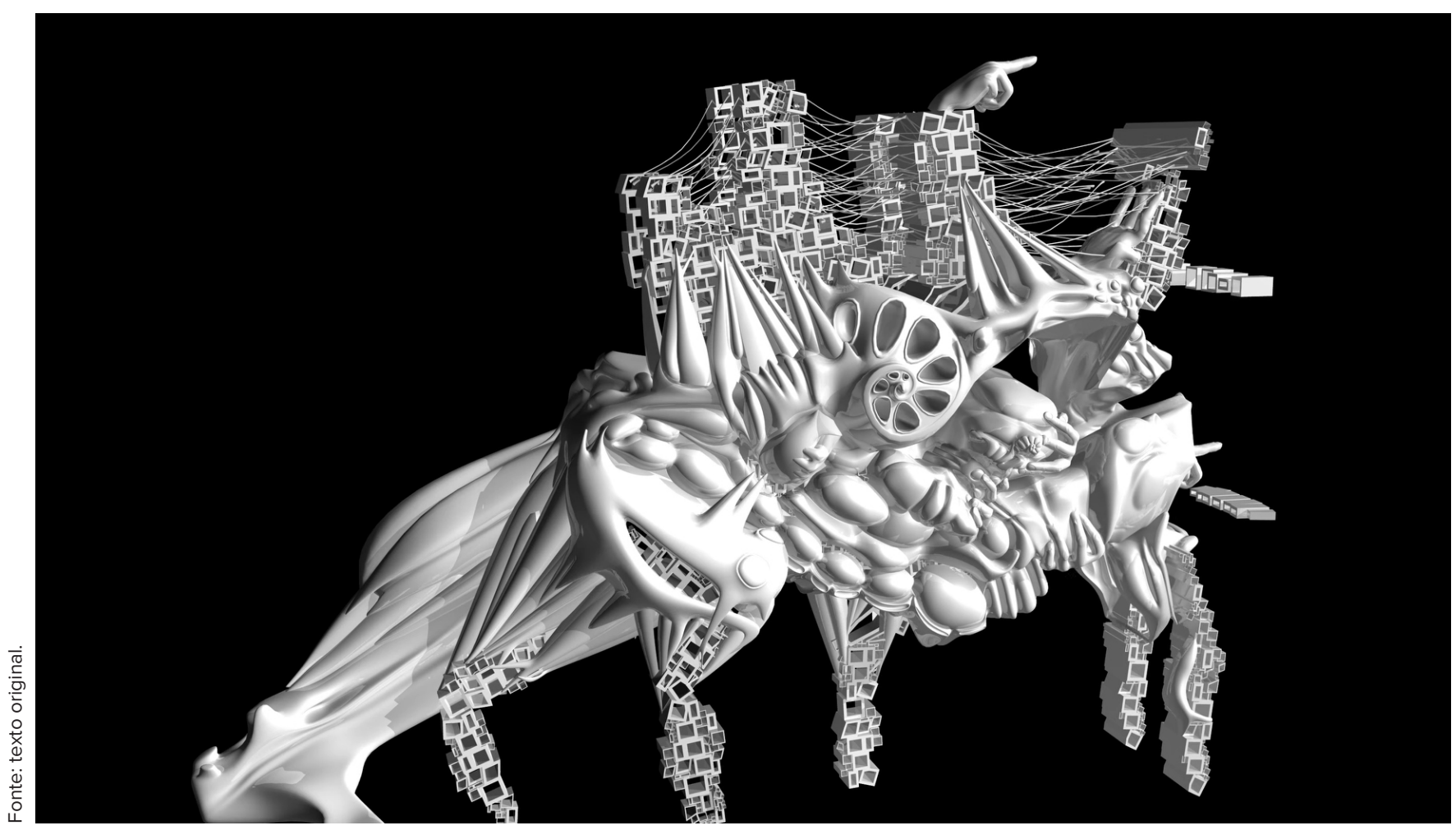

Figura 1. Hilary Koob-Sassen, Speech Acts of a Different Sort, 2012, vídeo (Bienal de Arquitetura de Veneza).

coletiva entre o espaço urbano e as pessoas. Por exemplo, a hora do rush na cidade é um processo em que nos chocamos com outras pessoas, um botão é arrancado aqui e ali, pisamos no pé do outro. Mas sabemos que nenhuma dessas ações é pessoal no centro da cidade na hora do rush, ao contrário de um bairro, onde isso seria visto como provocações.

O que torna isso possível é o código tácito inscrito naquele tipo de espaço/tempo - não um lugar em si, mas o espaço que é constituído pelas pessoas no centro da cidade na hora do rush. Precisamos nomear essa capacidade, que é um produto coletivo que emerge da interseção de tempo/espaço/pessoas/práticas rotineiras. Eu penso nisso como uma capacidade urbana - uma centralidade urbana é produzida por meio de ambientes construídos, práticas rotineiras das pessoas e um código inscrito e compartilhado. Permite uma série de interações e sequências complexas e, ao fazê-las, mobiliza um significado específico.

Não é só o resultado, mas o próprio trabalho de fazer o público e fazer o político no espaço urbano que constitui o ser cidade. Nas cidades, podemos ver a produção de novos sujeitos e identidades que não seriam possíveis, por exemplo, no meio rural ou em um país inteiro. Há um certo tipo de operação de configuração pública que pode perturbar narrativas estabelecidas e, portanto, tornar legíveis o local e o silenciado, até mesmo em ordens visuais que buscam purificar o espaço urbano. Um exemplo é o primeiro movimento sofisticado de gentrificação em Manhattan — uma ordem visual inteiramente nova que não conseguiu, por muito tempo, tornar invisíveis os sem-teto que produziu. Um segundo exemplo é o imigrante que trabalha como vendedor ambulante em Wall Street servindo refeições para executivos de alto escalão apressados, alterando a paisagem corporativa com os odores encorpados de salsichas cozidas. Eu vejo nesses exemplos a cidade nos contestando, alterando o fim almejado com a adoção de elegantes ordens visuais. No outro extremo, a sociabilidade de uma cidade pode trazer à tona $\mathrm{e}$ sublinhar a urbanidade do sujeito e do contexto e diluir significantes mais locais ou mais essencialistas. A necessidade de novas solidariedades, quando as cidades enfrentam grandes desafios, pode promover essa mudança.

Em minha pesquisa, entendo que os principais componentes do ser cidade foram feitos a partir do difícil trabalho de ir além dos conflitos e do racismo que podem marcar uma época (SASSEN, 2008, cap. 6). Desse tipo de dialética, surge a urbanidade aberta que historicamente fez das cidades europeias espaços de uma cidadania ampliada. De maneira mais 
geral, os movimentos que envolvem grupos distintos com uma variedade de reivindicações podem se unir, não importa quão diversas sejam suas políticas. A real interdependência vivida no dia a dia da cidade torna essa união possível - se houver falta de água, luz ou transporte em uma cidade, isso afeta a todos, independentemente de suas diferenças sociais ou políticas. Tal união seria improvável e desnecessária no espaço político nacional, dada a menor dependência/interdependência mútua e, em geral, em um espaço mais abstrato. Essas ordenações parciais que vemos nas cidades podem ser adicionadas ao DNA do civismo da cidade: elas alimentam a construção do sujeito urbano, ao invés de um sujeito baseado na religião, etnia ou classe. Esses são alguns dos fatores que fazem das cidades um espaço de grande complexidade e diversidade.

As grandes cidades no cruzamento de extensas migrações e expulsões foram e são espaços com capacidade para acomodar uma enorme diversidade de grupos. Essa acomodação geralmente é o resultado do desenvolvimento aprofundado de ser cidade - seja isso ou segregações espaciais que desurbanizam uma cidade. Deve-se notar que, quando bem-sucedidas, tais cidades permitem uma espécie de coexistência pacífica por longos períodos. Coexistência não significa respeito mútuo e igualdade: minha preocupação é com os aspectos construídos e os constrangimentos das cidades que produzem essa capacidade de interdependência, mesmo que haja grandes diferenças de religião, política, classe ou mais. Penso nas capacidades urbanas mais análogas com a infraestrutura ou capacidades subterrâneas, cujos resultados são em parte moldados pela necessidade de se manter um sistema complexo marcado por uma enorme diversidade e incompletude. Isso dá voz à cidade.

Talvez os casos mais conhecidos e claros sejam períodos de coexistência pacífica em cidades com diferenças religiosas bem definidas; isso deixa claro que o conflito não é necessariamente inerente a tais diferenças. Não são apenas os famosos casos de Augsburg ou da Espanha mourisca, com suas admiradas coexistências de religiões muito diversas, prosperidade coletiva e lideranças iluminadas. É também o caso do antigo bazar de Jerusalém, como espaço de convivência comercial e religiosa ao longo dos séculos. Bagdá prosperou como uma cidade polirreligiosa sob o califado abássida, por volta dos anos 80o, e mesmo sob a liderança extremamente brutal de Saddam Hussein foi uma cidade onde minorias religiosas, como comunidades cristãs e judaicas, geralmente com séculos de idade, viviam em relativa paz. Mas a História também nos mostra que isso é uma capacidade que pode ser destruída, e muitas vezes foi destruída. A destruição levou inevitavelmente à desurbanização e à formação de guetos no espaço urbano. Assim, em nítido contraste com períodos anteriores, Bagdá é hoje uma cidade onde a purificação étnica e a intolerância são o "regime" de fato, catapultado pela invasão desastrosa e injustificada dos Estados Unidos. Esses e muitos outros casos históricos mostram que um evento particularmente exógeno, de fato desurbanizante, pode reposicionar repentinamente diferenças religiosas ou étnicas como agentes de conflito. Os próprios indivíduos podem experimentar e representar essa mudança. A lógica sistêmica da Bagdá de Hussein era a indiferença às minorias como as cristãs e judaicas, não uma questão de tolerância por parte dos residentes ou liderança esclarecida.

Meu argumento é que a indiferença sistêmica pode, em muitos casos, funcionar como um tipo de capacidade urbana subterrânea em ação: um civismo que não depende da tolerância dos cidadãos ou líderes esclarecidos, mas é o resultado de interdependências e interações na vida física e econômica da cidade. Por outro lado, sua falência se torna visível como um colapso em conflitos letais e limpezas étnicas que desorganizam a cidade e violam a capacidade urbana.

Versões de capacidades urbanas podem ser encontradas em vários casos, alguns mais elusivos do que outros. Um deles diz respeito à questão da repetição, característica básica do ambiente construído nas cidades e, em geral, de nosso mundo econômico e técnico. Porém, na cidade, a repetição se torna a produção ativa de multiplicação e iteração. Além disso, as configurações urbanas de fato perturbam o significado da repetição. Há muita repetição em qualquer cidade, mas é sempre tomada pelo específico, pelas condições ao longo dos diferentes espaços urbanos. Um ônibus, uma cabine telefônica, um prédio de apartamentos ou escritórios, mesmo que se repitam padronizados em toda a cidade, terão diferentes significados e usos ao longo dos diversos tipos de espaços da cidade. Isso torna visível como a diversidade dos ambientes urbanos altera até os objetos mais padronizados e os torna parte desse bairro, desse espaço público, desse centro da cidade. Em um nível mais complexo, bairros de uma mesma cidade podem ter diferentes auras, sons, cheiros, coreografias de como as pessoas se movem neles, bem como a definição de quem é bem-vindo e quem não é. Em suma, a repetição na cidade pode ser muito diferente da repetição mecânica em uma linha de montagem ou da reprodução de um gráfico. Quero dar um passo adiante e sugerir que, em

Revista online do Departamento de Arquitetura e Urbanismo da Pontifícia Universidade Católica do Rio de Janeiro - PUC-Rio, Brasil Ano 8 - NNo 9 - ISSN 2446-7340 
cada instância dessas, vemos uma capacidade que gostaria de entender como fala.

Uma forma de voz mais difícil de definir é a construção da presença. No meu próprio trabalho, desenvolvi as noções de "fazer presença" para resgatar um agente ou um acontecimento do silêncio da ausência, da invisibilidade, do despejo virtual/representativo de pertencer à cidade.

Estou particularmente interessada em compreender como grupos e "projetos" em risco de invisibilidade por preconceitos e medos sociais se fazem presentes a si próprios, a outros semelhantes a eles e aos que são diferentes. O que eu quero entender é um recurso muito especial. É a possibilidade de se fazer uma presença onde há silêncio e ausência. Uma variante dessa construção de presença é o terrain vague, um espaço subutilizado ou abandonado que fica esquecido entre gigantes estruturas e projetos em construção. Não é exclusivo do nosso tempo - sob outros arranjos e com peculiaridades diferentes, também existiu no passado. Acho que esse espaço intermediário indescritível é essencial para a experiência da vida urbana e que fornece legibilidade para as transições, bem como o desconforto de configurações espaciais específicas. Podemos encontrar terrain vague mesmo nas cidades mais densas. Com a sua marca visual de espaço subutilizado, está normalmente carregado de memórias de outras ordens visuais, com presenças do passado, perturbando o seu significado atual como espaço não utilizado. Ele é carregado precisamente porque não é usado. Enquanto memórias, esses espaços passam a fazer parte da "interioridade" da cidade, do seu presente, mas é a construção de uma interioridade que foge à lógica dominante e às suas demarcações espaciais pautadas pelo benefício econômico. São as terras vazias que permitem aos residentes que se sentem oprimidos pela sua cidade se conectarem com ela através da memória em um momento de mudanças rápidas, um espaço vazio que pode ser preenchido com memórias. É aí que ativistas e artistas encontram espaço para seus projetos. Essa é uma construção de presença que é um ato de fala.

\section{Forças Desurbanizadoras}

Dada sua complexidade e incompletude, as cidades têm historicamente demonstrado capacidade de sobreviver a levantes, em parte por contestar e em parte por limitar as tendências de desurbanização. Mas elas nunca são totalmente bem-sucedidas. O poder, seja na forma de elites, políticas governamentais ou inovações no ambiente construído, pode

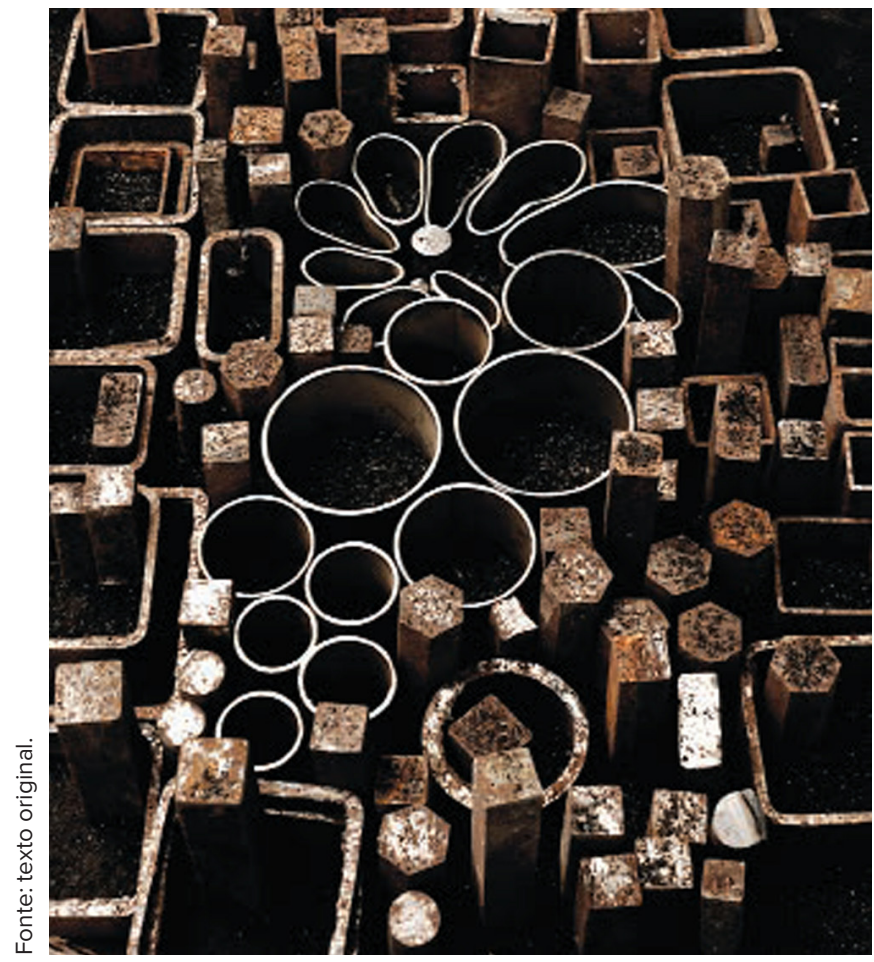

Figura 2. Hilary Koob-Sassen, Subterranean Shapes, 2012, vídeo (Bienal de Arquitetura de Veneza).

apagar a voz da cidade. Vemos isso no desenvolvimento de megaconstruções, rodovias que cruzam a cidade, extrema gentrificação para pessoas de alta renda que privatiza o espaço urbano, a proliferação de grandes concentrações de prédios residenciais de baixa qualidade e sem centros comerciais ou locais de trabalho, entre outros. Tudo isso faz parte das correntes de desurbanização atuais.

Em nossa época, significados estáveis se tornam instáveis. A grande e complexa cidade, com toda sua diversidade, é uma nova zona fronteiriça. Isso é especialmente verdadeiro na cidade global, definida por sua formação parcial em uma rede de outras cidades para além de seus limites. Atores de mundos diferentes estão lá, mas sem regras claras de engajamento. Onde a fronteira histórica estava nos extremos dos impérios coloniais, hoje se encontram em nossas grandes e complexas cidades. Por exemplo, muito do trabalho das empresas globais para impulsionar a desregulamentação, privatização e novas políticas fiscais e monetárias toma forma e se materializa em cidades globais. É a maneira pela qual as empresas globais constroem o equivalente ao antigo forte militar na fronteira histórica: sua rede de fortes é o ambiente regulatório que precisam em uma cidade após a outra, em todo o mundo, para garantir o espaço global de seus negó-

Revista online do Departamento de Arquitetura e Urbanismo da Pontifícia Universidade Católica do Rio de Janeiro - PUC-Rio, Brasil Ano 8 - NNo 9 - ISSN 2446-7340 
cios (SASSEN, 2008, cap. 5). É um ataque formidável contra a cidade e sua capacidade de assegurar seus atributos, o ser cidade.

Em minha pesquisa sobre a era atual (SASSEN, 2014), examinei especialmente três tipos de empreendimentos que podem desurbanizar a cidade. Um é o intenso crescimento de desigualdades de diferentes tipos que podem gerar expulsões radicais - de casas e bairros ou do estilo de vida das classes médias. Essas tendências são particularmente agudas e visíveis nas cidades, com seus espaços ampliados de luxo e pobreza. A segunda é a construção de novas cidades por completo, incluindo cidades inteligentes que muitas vezes são construídas como um negócio com fins lucrativos; há mais de seiscentas novas cidades em construção ou em planejamento. De particular preocupação é o uso extremo de sistemas inteligentes fechados para controlar edifícios inteiros. Dada a obsolescência acelerada da tecnologia, isso poderia encurtar a vida de uma grande área dessas novas cidades. Um desafio, a meu ver, é a necessidade de urbanizar essas tecnologias para que possam contribuir com a urbanidade dessas áreas. $\mathrm{O}$ terceiro projeto diz respeito a sistemas de vigilância em grande escala que estão atualmente em desenvolvimento em países como os Estados Unidos, Alemanha ou Reino Unido. Abordarei esse aspecto com mais detalhes a seguir.

Em julho de 2010, o Washington Post publicou os resultados de uma investigação de dois anos, Top Secret Ameri$c a$, em três partes (PRIEST e ARKIN, 2010a, 2010b, 2010c). Na configuração dessa "América ultrassecreta” participam 1.271 organizações governamentais e 1.931 empresas privadas, que juntas empregam cerca de 854 mil pessoas com autorização de alta segurança - quase $\mathbf{1 5 0} \%$ do número de pessoas que vivem em Washington, D.C. - incluindo 265 mil empreiteiros particulares (PRIEST e ARKIN, 2010a). Eles trabalham em programas relacionados ao contraterrorismo, segurança interna e inteligência. Existem cerca de 10.000 locais onde esse trabalho é feito nos Estados Unidos. Desses edifícios, quatro mil estão na área de Washington, D.C., e ocupam mais de 1,5 milhão de metros quadrados - o equivalente a quase três vezes o Pentágono, ou vinte vezes o edifício do Capitólio (PRIEST e ARKIN, 2010a).

Esses prédios abrigam computadores poderosos que coletam uma grande quantidade de informações por meio de grampeamento de telefones, satélites e outros equipamentos de vigilância que monitoram pessoas e lugares dentro e fora do território dos Estados Unidos. Todos os dias, a Agência de Segurança Nacional (NSA, na sigla em inglês) sozinha intercepta e armazena 1,7 bilhão de $e$-mails, mensagens instantâneas, endereços IP, chamadas telefônicas e outros fragmentos de comunicação; uma pequena proporção de tudo isso é classificada e armazenada em setenta bancos de dados diferentes (PRIEST e ARKIN, 2010a, 2010c). Algumas dessas informações chegarão a dezenas de milhares de relatórios ultrassecretos produzidos por analistas a cada ano, mas apenas um punhado de indivíduos tem acesso a eles, e o volume é tão grande que muitos nunca serão lidos (PRIEST e ARKIN, 2010a, 2010c).

Esse dispositivo de vigilância existe para nossa "segurança". Para nossa segurança, somos vigiados; ou seja, todos nós somos considerados suspeitos, para nossa própria segurança. Isso me leva a questionar se, nessas condições, nós, os cidadãos, não passamos de novos colonizados.

As cidades, com a suas diversidades e anarquias, com as suas capacidades incluídas para contestar as tendências de desurbanização, se tornam um espaço estratégico para se contestar a nossa redução à condição de suspeitos. A cidade é o único espaço em que algum tipo de convergência estrutural pode se desenvolver, sob a separação e o racismo visíveis e familiares, e se resolver no plano social para unir pessoas de comunidades muito diversas a fim de combater a vigilância avassaladora. Esse potencial não cai pronto do céu, ele precisa ser construído com muito trabalho. Mas cidades diversas e complexas são um local-chave para tal construção.

\section{Conclusão}

Por que é importante que reconheçamos o fato das capacidades urbanas e a possibilidade de que isso possa ser um modo de fala, com todo o peso que esse conceito evoca? Importa porque essas capacidades são propriedades sistêmicas destinadas a garantir o ser cidade, ou seja, um espaço complexo que prospera na diversidade e tende a alocar o conflito em um espírito cívico fortalecido.

Além disso, essas capacidades se constituem como híbridos - misturas da física material e social da cidade. Essa interdependência implica uma transformação contínua do material e do social, com períodos de estabilidade e continuidade e outros de convulsão, como o atual que se iniciou nos anos oitenta.

O projeto não busca antropomorfizar a cidade. Trata-se de compreender uma dinâmica sistêmica que tem a capacidade

Revista online do Departamento de Arquitetura e Urbanismo da 
de combater o que destrói o seu DNA - repetindo, um DNA que conduz ao ser cidade e à sua diversidade. No extremo, a cidade permite a quem não tem poder fazer história e, assim, produzir uma diferença crítica, entre uma forma simples e outra mais complexa de falta de poder, onde fazer presença e fazer história entram em jogo.

Mas há limites para as capacidades das cidades e, historicamente, vemos tanto a capacidade das cidades de sobreviver a sistemas formalmente mais fechados e rígidos, quanto às forças poderosas que desurbanizam as cidades. Atualmente, entre essas forças de desurbanização, estão formas extremas de desigualdade, privatização do espaço urbano com várias formas de expulsão e rápida expansão da vigilância em massa de cidadãos nas democracias mais "avançadas" do mundo. Essas forças silenciam a voz da cidade e destroem suas capacidades urbanas.

\section{Notas de fim:}

1. Nota do tradutor: o termo original speech tem sentido plurívoco na língua portuguesa. Nesta tradução, optou-se por traduzi-lo como voz ou fala de maneira pontual a melhor fazer sentido no contexto da frase, preferindo uma tradução adaptativa ao invés de singular ao longo do texto.

2. Nota do tradutor: apesar da palavra "urbano" não ser um substantivo como sinônimo de cidade, tanto na língua portuguesa quanto na língua inglesa, Sassen faz uso da palavra se referindo à condição complexa da cidade além de sua matéria construída.

3. Nota do tradutor: como não há duas palavras no português para diferenciar o termo original (capability) de seu quase-sinônimo ( $c a^{-}$ pacity), é relevante salientar que, no inglês, o primeiro, utilizado na versão original, carrega um sentido de potencial, uma característica que pode ser desenvolvida.

4. Nota do tradutor: Para Sassen, o conceito de "fronteira" diz respeito a uma região (borderland), mais do que uma linha propriamente dita.

5. Uso voz [e fala] no senso abstrato da lei, como, por exemplo, no modo como as corporações têm voz, conforme exposto pela Suprema Corte [dos Estados Unidos] em 2010 no caso Citizens United v. Federal Election Commission, que manteve os direitos de corporações de realizar financiamentos políticos sob o direito de liberdade de expressão da Primeira Emenda [à Constituição dos Estados Unidos]. Cidades, como corporações, não falam na voz humana; falam na sua voz.

6. Nota do tradutor: de modo simplificado, la passeggiata e piazza, em italiano, são expressões com valor cultural que, respectivamente, designam um passeio em grupo pela cidade à noite e um lugar onde pessoas se congregam socialmente.

\section{Referências Bibliográficas:}

PRIEST, Dana; ARKIN, William M. A hidden world, growing beyond control. Washington Post, Washington, D.C., 19 jul. $2010 a$.

National Security Inc. Washington Post, Washington, D.C., 20 jul. 2010b.

. The secrets next door. Washington Post, Washington, D.C., 21 jul. 2010c.

SASSEN, Saskia. Territory, authority, rights: from medieval to global assemblages. 2. ed. Princeton: Princeton University Press, 2008.

The global street: making the political. Globalizations, Abingdon, v. 5, n. 8, p. 565-71, 2011.

. Expulsions: when complexity produces elementary brutalities. Cambridge: Harvard University Press, 2014. 